\title{
Total Phenolic Content and Antioxidant Activity of Spilanthes Species from Peninsular India
}

\author{
Lavanya Devi $K^{1 *}$, Shivanna $M B^{2}$, Ganeshan $S^{3}$
}

${ }^{1,3}$ Division of Plant Genetic Resources, Indian Institute of Horticultural Research, Hessaraghatta, Bangalore-89, India.
${ }^{1,2}$ Department of Applied Botany, Jnana Sahyadri, Kuvempu University, Shankaraghatta, Shimoga, Karnataka, India.

*Corresponding author: Lavanya Devi K, Division of Plant Genetic Resources, Indian Institute of Horticultural Research, Hessaraghatta, Bangalore-89, India., E-mail: lavanyakotekar@gmail.com

Received: April 06, 2017; Revised: July 26, 2017; Published: August 17, 2017

Copyright: (02017 Lavanya DK, et al. This is an open-access article distributed under the terms of the Creative Commons Attribution License, which permits unrestricted use, distribution, and reproduction in any medium, provided the original author and source are credited. The article has been previewed and authenticated by the Authors before sending the publication for print. The Journal, Editor and the Editorial Board are not entitled or liable to either justify or responsible for inaccurate and misleading data if any. It is the sole responsibility of the Author concerned.

Citation: Lavanya DK, Shivanna MB, Ganeshan S. Total Phenolic Content and Antioxidant Activity of Spilanthes Species from Peninsular India. Int J Pharm Pharmacol 2017; 1: 115. doi: 10.31531/2581$\underline{3080.1000115}$

\begin{abstract}
Spilanthes is a genus of herbs belonging to Asteraceae family commonly known as "Toothache plant". The inflorescence is used for treating sore throat, stammering and redness of gums and is known to have anti-malarial, anti-diuretic and anti-inflammatory properties. It has been reported that they show high antioxidant activity, in the present study, the antioxidant activity was measured in terms of Ferrous Reducing Antioxidant Power (FRAP) for six species of Spilanthes and total phenolic content. Spilanthes ciliata leaves were found to have highest total phenolic content $(21.53 \mathrm{mg} / \mathrm{g}$ of GAE). Lowest value was recorded in Spilanthes oleracea. Leaves showed more phenols compared to the other parts. Inflorescence showed moderate activity with maximum recorded in S. oleracea. In roots, the total phenolic content was moderate with the maximum recorded in $S$. ciliata and minimum in $S$. radicans. In FRAP assay, the maximum activity was observed in S. ciliata followed by $S$. calva and minimum was observed in S. radicans. Among inflorescence, S. calva and S. oleracea showed higher activity compared to other parts of all other species. Inflorescence of all the other species showed moderate activity. In roots, the antioxidant activity was maximum in S. ciliata and S. uliginosa recorded least activity with maximum reading in $S$. calva leaves $=0.381$, minimum in $S$. uliginosa, root=0.23, among leaves highest frap reading was obtained in $S$. calva and in roots $S$. calva and $S$. oleracea both showed equal FRAP readings and in Inflorescence maximum was in S. calva followed by S. oleracea. This is the first report of comparison of six species of Spilanthes with different plant parts for total phenolic compounds and FRAP assay.
\end{abstract}

Keywords: Asteraceae, Spilanthes, Total Phenolic Content, Gallic Acid Equivalents, Ascorbic acid Equivalent Antioxidant Capacity, Ferrous Reducing Antioxidant Power, Antioxidant activity 
Abbreviations: TPC: Total Phenolic Content; GAE: Gallic Acid Equivalents; AEAC: Ascorbic acid Equivalent Antioxidant Capacity; FRAP: Ferrous Reducing Antioxidant Power, DDW: Double Distilled Water.

\section{Introduction}

Medicinal plants are remedy sources for human diseases because they contain chemical components of therapeutic value [1]. A systematic study of medicinal plants is very important to identify find active compounds, for their use in neutraceutical, cosmetic and pharmaceutical industries [2,3]. Contemporary researchers have taken a great interest in medicinal plants for their phytochemical constituents and related total biological activities including antioxidant activity [4-6]. Spilanthes is a genus of herbs belonging to Asteraceae family, commonly known as toothache plant widely used in folklore medicine. Spilanthes acmella is a wonder drug possessing analgesic, antibiotic, antimalarial [7], diuretic [8] and anti-inflammatory activities. It is a common spice, used as salad ingredient and has been administered as traditional folk medicine for years to cure toothache [9], stammering and stomatitis.

The antifungal activity of Spilanthes species was recorded with Fusarium moniliformis, Fusarium oxysporium, Aspergillus niger, and Aspergillus paraciticus. The active ingredient of Spilanthes is an alkamide called Spilanthol presence of which gives medicinal properties to this plant. The spilanthol, inhibits the contractions of subcutaneous muscle especially facial muscles hence commercially used in the anti-aging products.

An adequate intake of natural antioxidants could protect the onset of oxidative damage in cells [10]. The term antioxidant refers to compounds which can scavenge free radical, inhibit lipid peroxidation and act as chelating agent [11]. Phenolic compounds overcome this definition as they possess a wide spectrum of biological effects including antioxidant and free radical scavenging activities [12]. Therefore, a great interest has been recently focused on the natural foods, medicinal plants and phytoconstituents due to their well-known abilities to scavenge free radicals. The antioxidant capacity of the plant extract largely depends on both the composition of the extract and the test system. It can be influenced by a large number of factors and cannot be fully evaluated by one single method. It is necessary to perform more than one type of antioxidant capacity measurement to take into account the various mechanisms of antioxidant action [13]. Hence the antioxidant activity was evaluated by FRAP assay. In this assay, the antioxidant capacity is measured on the basis of the ability of antioxidants to reduce $\mathrm{Fe}^{3+}$ to $\mathrm{Fe}^{2+}$ in the presence of 2,4,6-tripyridyl-s-triazine (TPTZ), forming an intense blue $\mathrm{Fe}^{2+}$ TPTZ complex with an absorption maximum at $593 \mathrm{~nm}$ and can be applied to both aqueous and alcohol extracts of plants.

In the present study, six species of Spilanthes genus collected from different locations in Peninsular India region and maintained in field gene bank at IIHR, Bangalore were analyzed for antioxidant activity in terms of total phenolic content which is reported to be directly responsible for the antioxidant activity of a species and by FRAP antioxidant assay.

\section{Materials and Methods}

\section{Plant Material}

The six species of Spilanthes viz. S. calva (DC.) R.K, S. ciliata (Kunth) Cassini, $S$. oleracea Linnaeus R.K. Jansen, S. paniculata Wallich ex DC, $S$. radicans (Jacquin) R.K. Jansen and S. uliginosa (Swartz) Cassini were collected from different parts of Peninsular India region during 2011-2013 and the voucher specimens are deposited in cryo-bank of division of Plant Genetic Resources, Indian Institute of Horticultural Research, Bangalore, Karnataka. The total phenolic assay was carried out in all plants during the full flowering stage. Three types of plant material namely leaves, inflorescence and roots were collected from the plants grown in the field gene bank of Division of Plant Genetic Resources, Indian Institute of Horticultural Research, Bangalore. The 
methanolic extract of the sample was prepared by dissolving $5 \mathrm{~g}$ of the plant material in $20 \mathrm{ml}$ of methanol and made up to $50 \mathrm{ml}$ using DDW.

\section{Determination of Total Phenolic Content}

The total phenolic content in the Spilanthes species extracts was determined spectrophotometrically following the FolinCiocalteu's method [14] using gallic acid as a standard (the concentration range: 0.025 to 0.5 $\mathrm{mg} / \mathrm{ml}$ ). Acidic methanol extract was mixed with Folin-Ciocalteu Reagent (Merck Co. Ltd., Darmstadt, Germany), and the color was developed using 20\% sodium carbonate reagent. Intensity of color developed was read by measuring the absorbance at $700 \mathrm{~nm}$ using a spectrophotometer (Beckmann DU64, Beckmann Instruments International, SA, Nyon, Switzerland). Results were expressed as milligrams of gallic acid equivalents per $100 \mathrm{~g}$ dry weight.

\section{Ferric Reducing Antioxidant Potential (FRAP)}

Antioxidant capacity was measured as FRAP using a modified method of Benzie and Strain [15]. At low $\mathrm{pH}$, reduction of ferric tripyridyltriazine (Fe III-TPTZ) complex to the ferrous form by antioxidants present in the sample results in an intense blue color that was measured at $593 \mathrm{~nm}$ to estimate antioxidant capacity. The FRAP assay mixture, containing $200 \mu \mathrm{l}$ of the extract and $1.8 \mathrm{ml}$ of FRAP reagent, was incubated at room temperature for $40 \mathrm{~min}$ and absorbance was measured at 593 nm. The standard curve was prepared using ascorbic acid as an antioxidant. Antioxidant capacity was expressed as milligrams ascorbic acid equivalent antioxidant capacity (AEAC) per $100 \mathrm{~g}$ dry weight. The statistical analysis was carried out with MS Excel where the graph was developed for each species total phenol estimation and the comparison was carried out depending on which the results were interpreted.

\section{Results and Discussion}

\author{
Determination of Antioxidant Activity by \\ TPC
}

The TPC accounts for the antioxidant potential of plant species. The antioxidant assay indicated that $S$. ciliata leaves produced high TPC amounting to $21.53 \mathrm{mg} \mathrm{g}^{-1}$ of GAE; the lowest value was recorded in S. oleracea (4.53 $\left.\mathrm{mg} \mathrm{g}^{-1}\right)$. Leaves produced more TPC as compared to the other plant parts. The inflorescence showed moderate content; high content (10.48 $\mathrm{mg} \mathrm{g}^{-1}$ ) was recorded in $S$. oleracea and least $\left(6.81 \mathrm{mg} \mathrm{g}^{-1}\right)$ in S. ciliata. The TPC in root was less; high content (13.7 $\left.\mathrm{mg} \mathrm{g}^{-1}\right)$ was recorded in $S$. ciliata and least (3.50 $\mathrm{mg} \mathrm{g}^{-1}$ ) in S. radicans (Figure 1).

\section{Determination of Antioxidant Activity by FRAP Assay}

The FRAP assay expressed antioxidant potential in terms of ACAE. The maximum antioxidant activity was detected in S. ciliata $\left(58.59 \mathrm{mg} \mathrm{g}^{-1}\right)$ followed by $S$. calva and least in S. uliginosa $\left(46.18 \mathrm{mg} \mathrm{g}^{-1}\right)$. The inflorescence of S. calva and S. paniculata $\left(\sim 73.30 \mathrm{mg} \mathrm{g}^{-1}\right)$ had highest activity. The antioxidant activity in root was highest $\left(58.61 \mathrm{mg} \mathrm{g}^{-1}\right)$ in $S$. ciliata and lowest $\left(43.16 \mathrm{mg} \mathrm{g}^{-1}\right.$ ) in S. uliginosa (Figure 2).

The ferrous reducing antioxidant potential was expressed in terms of ascorbic acid equivalents $/ \mathrm{g}^{-100}$ in different plant parts of Spilanthes.

The comparative study of antioxidant potential of species of Spilanthes by TPC and FRAP has not been documented in previous studies. The Mantel test carried out to find the correlation among TPC and FRAP exhibited positive correlation $(0.6695)$ and the $p$ value $(<0.025)$ showing significant correlation. Similar, this study established the antioxidant property of compounds in Spilanthes species. Phenolics are compounds possessing aromatic rings with hydroxyl groups [16], and react as hydrogen donors and neutralize the free radicals $[17,18]$. Although, reports are documented in Spilanthes calva and $S$. paniculata. This study gives comparison of six species of Spilanthes from peninsular India region. The documentation of antioxidant potential of phenolic and other compounds in Spilanthes species supported the previous recommendation of the plant species for their medical application. 


\section{References}

1. Marimuthu P, Wu CL, Chang HT et al. Antioxidant activity of the ethanolic extract from the bark of Chamaecyparis obtusa var. formosana. J Sci Food Agric 2008; 88: 1400-1405.

2. Canadanovic-Brunet JM, Djilas SM, Cetkovic GS, et al. Free-radical scavenging activity of wormwood (Artemisia absinthium L.) extracts. J Sci Food Agric 2005; 85: 265-272.

3. Nostro, A, Germanò MP, D'Angelo V, et al. Extraction methods and bioautography for evaluation of medicinal plant antimicrobial activity. Lett Appl Microbiol 2000; 30: 379-384.

4. Amarowicz R, Pegg RB, RahimiMoghaddam P, et al. Free-radical scavenging capacity and antioxidant activity of selected plant species from the Canadian prairies. Food Chem 2004; 84: 551-562.

5. Miliauskas G, Venskutonis PR, TA van Beek. Screening of radical scavenging activity of some medicinal and aromatic plant extracts. Food and Chem Tox 2004; 85: 231-237.

6. Rajesh M, Nagarajan A, Perumal S, et al. The antioxidant activity and free radical scavenging potential of two different solvent extracts of Camellia sinensis (L.) $O$. Kuntz, Ficus bengalensis L. and Ficus racemosa L. Food Chem 2008; 107: 10001007.

7. Pandey V, Agrawal V, Raghavendra K, et al. Strong larvicidal activity of three species of Spilanthes (Akarkara) against malaria (Anopheles stephensi Liston, Anopheles culicifacies, Species C) and Filaria vector (Culex quinquefasciatus Say). Parasitol Res 2007; 102: 171-174.

8. Ratnasooriya WD, Pieris P, Samaratunga $\mathrm{U}$, et al. Diuretic activity of Spilanthes acmella flowers in rats. J Ethnopharmacol 2004; 91: 251-257.
9. Ghani A. Medicinal plants of Bangladesh with chemical constituents and uses. $2^{\text {nd }}$ ed. Asiatic society of Bangladesh, Dhaka, Bangaldesh. 2003; 387.

10. Riso PF, Visioli, C, Gardana. Effect of blood orange juice intake on antioxidant bioavailability and on different markers related to oxidative stress. J Agric Food Chem 2005; 53: 941-947.

11. Lee JC, Kim J, Park JK, et al. The antioxidant, rather than prooxidant, activities of quercetin on normal cells: quercetin protects mouse thymocytes from glucose oxidase-mediated apoptosis. Exp Cell Res 2003; 291: 386-397.

12. Pellati F, Benvenuti S, Magro L, et al. Analysis of phenolic compounds and radical scavenging activity of Echinacea spp. J Pharm Biomed Anal 2004; 35: 289301.

13. Frankel EN, Meyer AS. The problems of using one dimensional method to evaluate multifunctional food and biological antioxidants. J Sci Food Agric 2000; 80: 1925-1941.

14. Singleton VL, Orthofer R, LamuelaRaventós RM. Analysis of total phenols and other oxidation substrates and antioxidants by means of folin-ciocalteu reagent. Methods in Enzymol 1999; 299: 152-178.

15. Benzie IEF, JJ Strain. The ferric reducing ability of plasma (FRAP) as a measure of antioxidant power: the FRAP assay. Anal Bioche 1996; 239: 70-76.

16. Liu RH. Whole grain phytochemicals and health. J Cereal Sci 2007; 46: 207-219.

17. Tanaka M, Kuie CW, Nagashima Y, et al. Applications of antioxidative Maillard reaction products from histidine and glucose to sardine products; Nippon Suisan Gakkaishi 1988; 54: 1409-1414.

18. Kulisic T, Radonic A, Katalinic V, et al. Use of different methods for testing antioxidative activity of oregano essential oil. Food Chem 2004; 85: 633-640. 


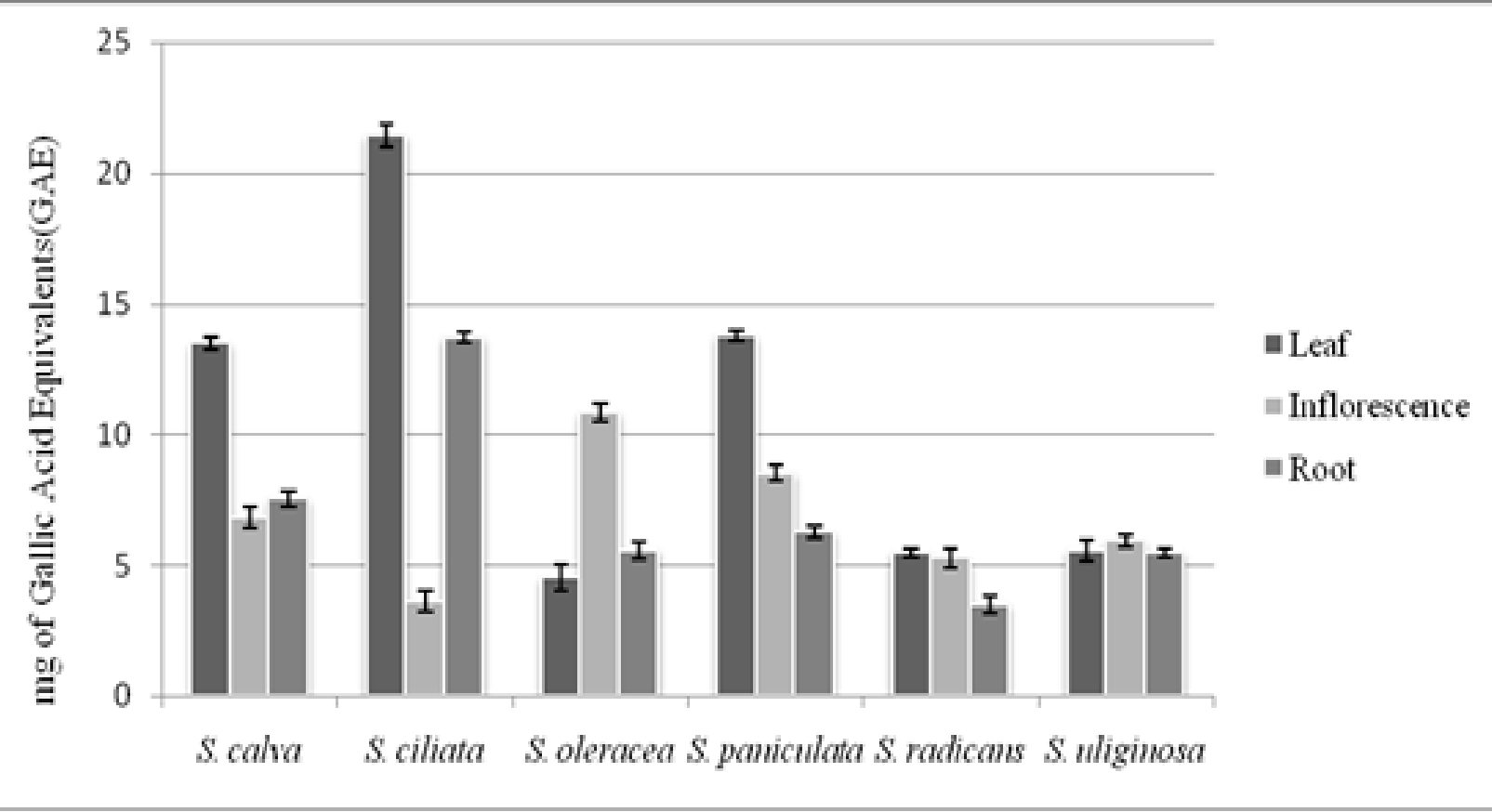

Figure 1: Total phenolic content in leaf, inflorescence and root extracts of Spilanthes species viz., Spilathes calva, $S$. ciliata, $S$. oleracea, $S$. paniculata, $S$. radicans and $S$. uliginosa concentration of extracts $(2 \mathrm{~g} / 50 \mathrm{ml})$.

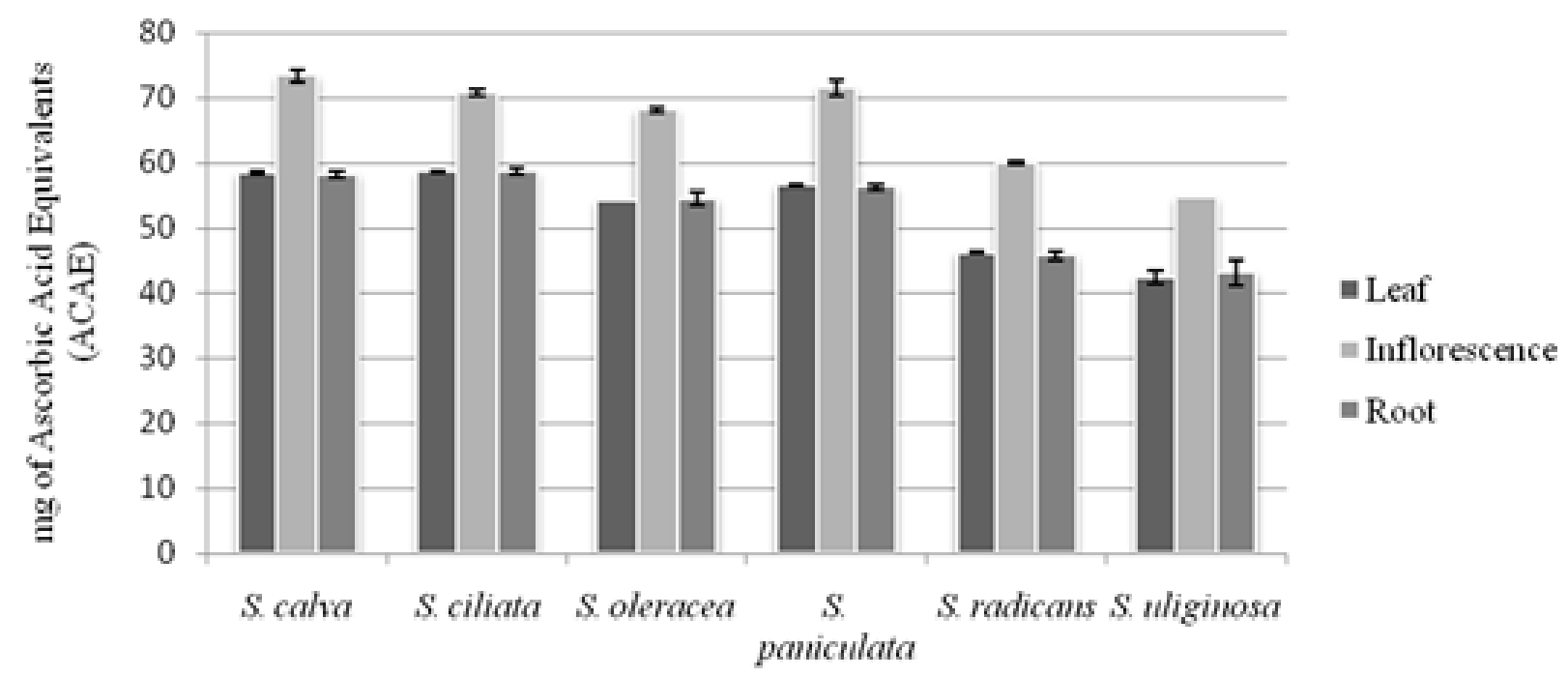

Figure 2: The antioxidant potential of leaf, inflorescence and root extracts of Spilanthes species viz., Spilathes calva, S. ciliata, S. oleracea, S. paniculata, S. radicans and $S$. uliginosa concentration of extracts ( $2 \mathrm{~g} / 50 \mathrm{ml}$ by FRAP assay). 
This manuscript was peer-reviewed

Mode of Review: Single-blinded

\section{Editor: Dr. Sabrin R. M. Ibrahim}

International Journal of Pharmaceutics and Pharmacology is an open access, peer reviewed journal published by Edwiser International.

Submit your valuable manuscript at-

editor.ijpp@edwiserinternational.com

submit.manuscript@edwiserinternational.com

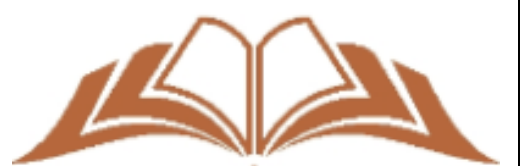

$\mathrm{E} D \mathrm{~W}(\hat{\theta} \mathrm{SER}$
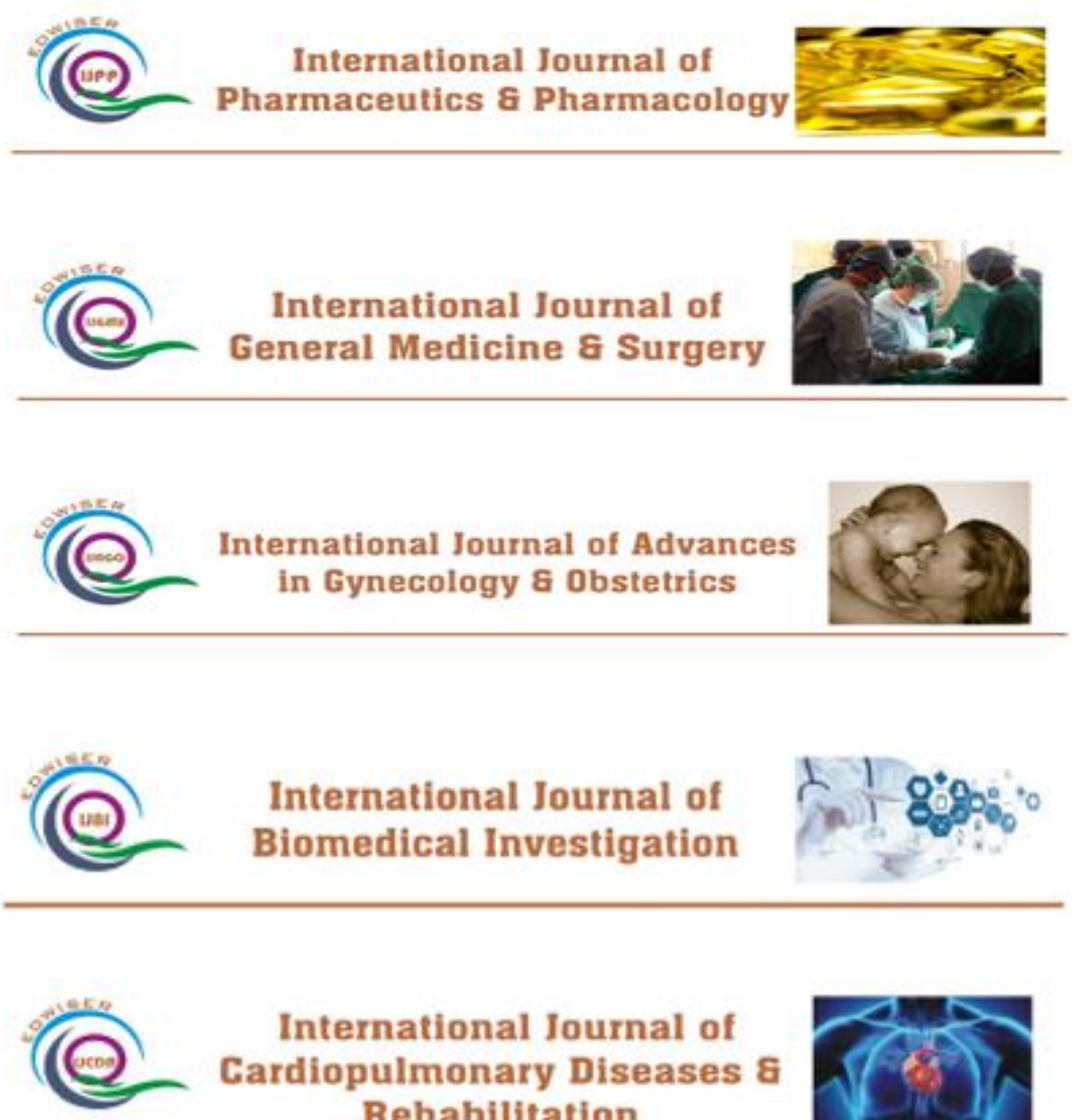

International Journal of Cardiopulmonary Diseases \& Rehabilitation 